\title{
The occurrence of bromine in some Finnish and imported vegetables determined by a polarographic method
}

Jorma Hirn ${ }^{1}$ ), Ruth Stabel-Taucher ${ }^{2}$ ) and Timo J. Peknanen ${ }^{1}$ )

1) Department of Food Hygiene, College of Veterinary Medicine, 00550 Helsinki 55

2) State Veterinary Medical Institute, 00550 Helsinki 55

\begin{abstract}
The bromide content of 59 Finnish and imported vegetable samples was determined by a modified polarographic method. 10 lettuce samples out of 20 were found to contain bromide in excess of $5 \mathrm{ppm}$ fresh matter, which is the maximum level tolerated for bromide in some countries. These lettuce samples originated from Holland and Spain. In addition the natural bromide level of $2 \mathrm{ppm}$ was exceeded in some conserved and fresh vegetable samples, but was always less than $5 \mathrm{ppm}$.
\end{abstract}

\section{Introduction}

The insecticidal activity of methyl bromide was first reported, in 1932, by Goupil (MARTIN 1972). After that many organic ccmpounds containing bromine, including methyl bromide, ethylene dibromide and 1,2-dibromo - 3-chloropropane, have been increasingly used as soil fumigants in or samental and vegetable crops. Bromine fumigants have proved to produce good control of nematodes, soil-borne fungi like Fusarium, corky root and most fungi causing "damping off" (Gollop 1974).

Bromine is a natural constituent of the environment. STÄrK and Süss (1973) have noted that the natural bromine content of many vegetables is almost always below $2 \mathrm{ppm}$ in fresh matter. On the other hand, high concentrations of bromine are found in lettuce and certain other vegetable grown on a soil fumigated with methyl bromide (Hoffmann and Malkomes 1974, Van WAMBEKE 1974). The purpose of this investigation was to determine the bromide contents of certain Finnish and imported vegetables, using a polarographic method developed by Beckman et al. (1967) and modified by the authors.

\section{Material and methods}

\section{Material}

The material consists of 59 vegetable sambles of which 20 were conserved vegetables originating from 10 different countries (Belgium, Finland, France, Holland, Italy, Jugoslavia, The People's Republic of China, The Republic of 
China, The Soviet Union, The German Federal Republic), 20 lettuce samples from four countries (Bulgaria, Egypt, Holland, Spain), six cucumber samples from three countries (Bulgaria, Holland, Spain), three Chinese cabbage (Chinese leaves) samples from Austria and four samples of strawberries from Poland. The samples were purchased from retail stores or remitted for analysis from the Customs Laboratory.

\section{Methods}

The bromine was determined polarographically according to a method developed by Beскмan et al. (1967). The cleaning-up procedure by which bromine was isolated and oxidized to bromate was adopted with only minor modifications. The polarographic technique was different, and the whole procedure is therefore described below.

Reagents. Sodium hypochlorite solution, BDH Chemicals Ltd., Egnland, low in bromine, approximately $1 \mathrm{~N}$ in $0.1 \mathrm{~N}$ sodium hydroxide.

Sodiumdichromate, $\mathrm{Na}_{2} \mathrm{Cr}_{2} \mathrm{O}_{7} \cdot 2 \mathrm{H}_{2} \mathrm{O}$, Riedel-de Haen Ag, W. -Germany. Sodium formate, Merck, W. -Germany, 3 M solution.

$\mathrm{NH}_{4} \mathrm{OH} / \mathrm{NH}_{4} \mathrm{Cl}$ solution, 5 M. $133.75 \mathrm{~g} \mathrm{NH}_{4} \mathrm{Cl}$ was dissolved in $340 \mathrm{ml}$ $\mathrm{NH}_{4} \mathrm{OH}$ and the volume adjusted to $500 \mathrm{ml}$ with water.

Equi pment. Polarograms were run on a PAR (Princeton Applied Research, Inc. New Jersey, U.S.A.) Model 174 Polarographic Analyzer, with a PAR Model 174/70 drop timer. The signals were recorded by a Portable $\mathrm{X}-\mathrm{Y} / \mathrm{t}$ Recorder Type 29 000-Model A 3 (Bryans Southern Instruments Ltd. Surrey, England). The sensitivies of the recorder axes were adjusted so that the fullscale output of the PAR 174 corresponded to $20 \mathrm{~cm}$ on the $\mathrm{y}$-axis and to 30 $\mathrm{cm}$ on the $\mathrm{x}$-axis. The cell was a $100-\mathrm{ml}$ Berzelius beaker which contained $25 \mathrm{ml}$ of test solution. It was fitted with a dropping mercury electrode (DME). To prevent uncontrolled dropping of mercury and to avoid the troublesome raising and lowering of the mercury supply funnel, a mercury cock with $\mathrm{Pt}$ contact to the drop timer was mounted on the mercury pillar. A saturated calomel electrode (SCE) from Beckman Instruments Ltd., Scotland served as the reference electrode, and a platinum wire was used as the counter electrode. Both the SCE and the Pt -electrode were placed directly in the solution. Nitrogen used for outgassing prior to the running of the polarogram was passed through the supporting electrolyte $\left(1 \mathrm{M} \mathrm{N} \mathrm{N}_{4} \mathrm{OH} / \mathrm{NH}_{4} \mathrm{Cl}\right)$ before entering the cell. A two-way stopcock was used to direct the nitrogen through the test solution or over its surface.

Procedure. $100 \mathrm{~g}$ of the vegetable material was blended with $200 \mathrm{ml}$ distilled water for $15 \mathrm{~min}$ at low speed. Then $150 \mathrm{ml}$ methanol was added and the blending continued for an additional $15 \mathrm{~min}$ at medium speed. The mixture was transferred to a $500 \mathrm{ml}$ volumetric flask, the blender rinsed out with methanol and the volume adjusted to $500 \mathrm{ml}$ with methanol. After the mixture had sedimented, a portion of the upper part of the solution was filtered and $125 \mathrm{ml}$ of the filtrate was added to a nickel crucible along with 2 pellets of $\mathrm{NaOH}$. The extract was dried overnight at $102^{\circ} \mathrm{C}$, then placed in a cold muffle furnace previously set to $600^{\circ} \mathrm{C}$ and incinerated until the ash was white. 
An oxidation apparatus as described by Beckman et al. (1967) was used to convert the inorganic bromide to bromine (reaction vessel A) and then to bromate (reaction vessel B). The reaction vessel A contained $50 \mathrm{~g} \mathrm{Na}_{2} \mathrm{Cr}_{2} \mathrm{O}_{7} \cdot 2 \mathrm{H}_{2} \mathrm{O}$, $35 \mathrm{ml}$ deionized water and $45 \mathrm{ml}$ concentrated $\mathrm{H}_{2} \mathrm{SO}_{4}$. The reaction vessel $\mathrm{B}$ was charged with $2 \mathrm{ml}$ of the $\mathrm{NaOCl}$ solution, $1 \mathrm{ml} 5 \% \mathrm{NaH}_{2} \mathrm{PO}_{4}$ and $5 \mathrm{ml}$ of deionized water. A gentle stream of air, $1.51 / \mathrm{min}$, controlled by a Matheson 621 PSX flowmeter, New Jersey, U.S.A. was drawn through the system.

The cooled ash was dissolved in $15 \mathrm{ml}$ distilled water. The crucible was washed out with two $15 \mathrm{ml}$ portions of water and the whole solution was transferred to the reaction vessel A through the connecting funnel. The distillation was allowed to proceed for $15 \mathrm{~min}$. Then the reaction vessel $\mathrm{B}$ was removed. The gas dispenser was washed with $4 \mathrm{ml}$ of water and $2 \mathrm{ml}$ of the $\mathrm{NaCHO}_{2}$ solution was added. The mixture was placed in a water bath at $100^{\circ} \mathrm{C}$ for $15 \mathrm{~min}$ to reduce the remaining hypochlorite. After cooling the solution was transferred to a $25 \mathrm{ml}$ volumetric flask, $5 \mathrm{ml}$ of the $\mathrm{NH}_{4} \mathrm{OH} / \mathrm{NH}_{4} \mathrm{Cl}$ solution was added and the volume adjusted to $25 \mathrm{ml}$ with water.

This solution was transferred to the cell of the polarograph. Nitrogen was passed through the solution for $5 \mathrm{~min}$ to remove oxygen. The polarogram was recorded from -1.0 to $-1.75 \mathrm{~V}$. The peak maximum appeared at $-1.56 \mathrm{~V}$. Figure 1 shows the polarogram of $1-6$ ppm of $\mathrm{BrO}_{3}-$ measured at a sensitivity of $20 \mu \mathrm{A}$. The peak heights were measured and converted into $\mu \mathrm{A}$ $(1 \mathrm{~cm}$ equalled $1 \mu \mathrm{A})$. A peak current - concentration curve (Figure 2) was produced on the basis of the data obtained. The curve was found to be linear over a wide range, at least up to $1000 \mathrm{ppm}$, which was the range of interest in this work.

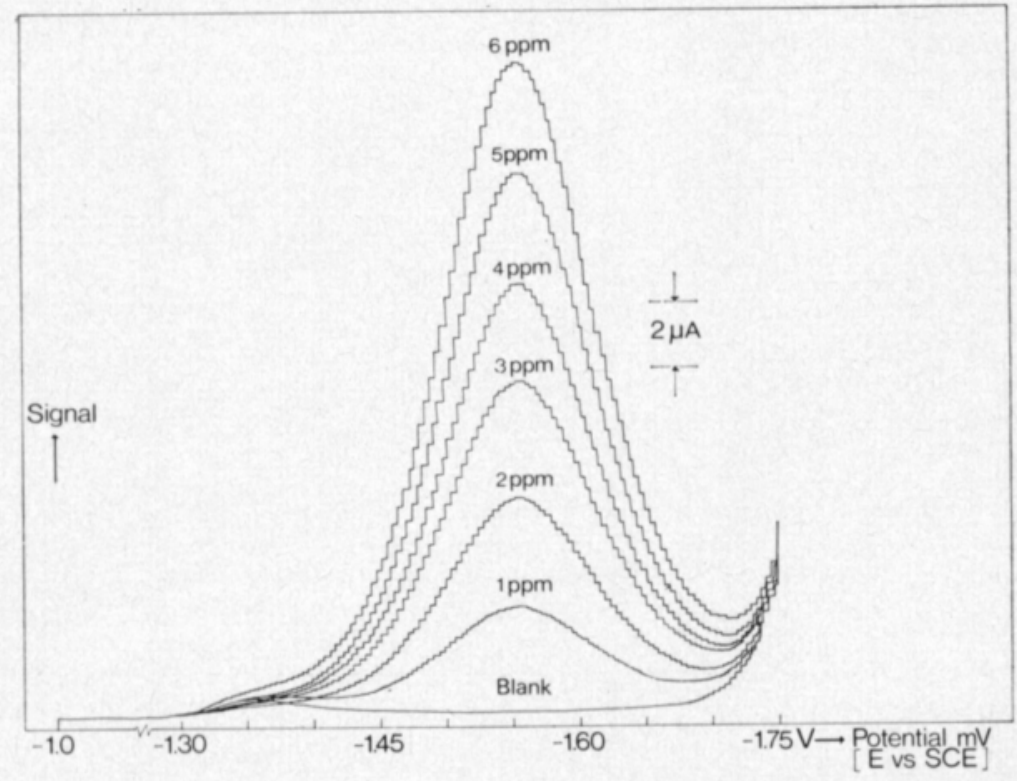

Fig. 1. Differential pulse polarogram of bromat ion in $1 \mathrm{M} \mathrm{NH} \mathrm{N}_{4} \mathrm{Cl} / \mathrm{NH}_{4} \mathrm{OH}$ buffer $[\operatorname{Br}(\mathrm{V})]=1-6 \mathrm{ppm}$. Scan rate $=2 \mathrm{~m} \mathrm{~V} / \mathrm{sec}$. Drop time $=2 \mathrm{sec}$. 


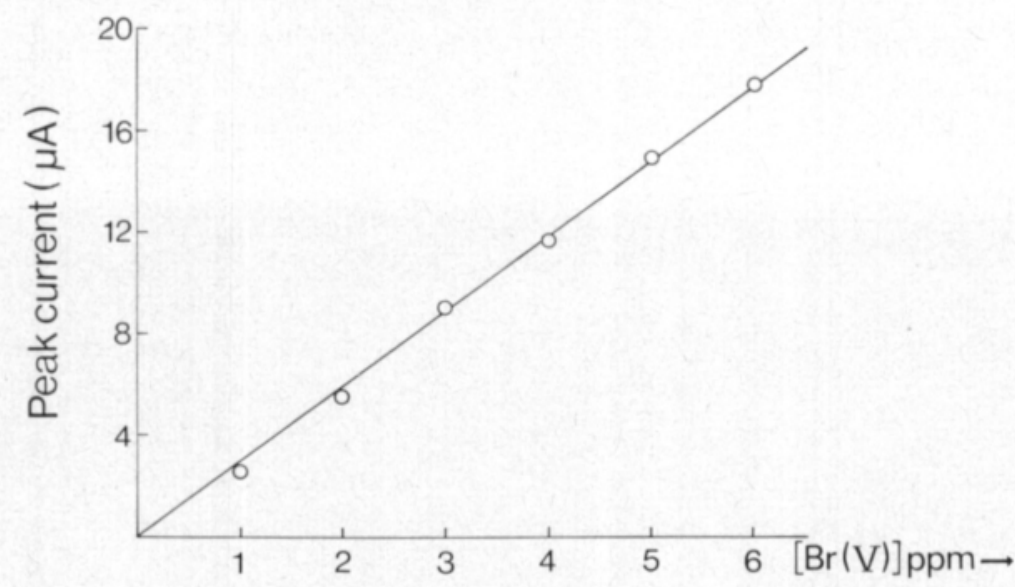

Fig. 2. Calibration curve of $\mathrm{Br}(\mathrm{V})$ from $1-6 \mathrm{ppm}$ at $-1.56 \mathrm{~V}$. Instrumental settings same as in fig. 1.

\section{Results}

The results of the bromide analyses of all vegetable samples are presented within given ranges in Table 1 .

Table 1. Bromide residues in certain fresh and conserved vegetables.

\begin{tabular}{|c|c|c|c|c|c|c|}
\hline \multirow[b]{2}{*}{$\begin{array}{c}\text { Bromide residues } \\
\mathrm{mg} / \mathrm{kg}^{*}\end{array}$} & \multicolumn{6}{|c|}{ Number of samples with bromide residues within given ranges } \\
\hline & $\begin{array}{l}\text { Conserved } \\
\text { vegetables }\end{array}$ & Lettuce & Tomato & Cucumber & $\begin{array}{l}\text { Chinese } \\
\text { gabbage }\end{array}$ & $\begin{array}{l}\text { Straw } \\
\text { berry }\end{array}$ \\
\hline$<2.00$ & 17 & 8 & 2 & 5 & 3 & 4 \\
\hline $2.00-4.99$ & 3 & 2 & 4 & 1 & 0 & 0 \\
\hline $5.00-9.99$ & 0 & 1 & 0 & 0 & 0 & 0 \\
\hline $10.00-49.99$ & 0 & 6 & 0 & 0 & 0 & 0 \\
\hline$\geqq 50.00$ & 0 & 3 & 0 & 0 & 0 & 0 \\
\hline Total & 20 & 20 & 6 & 6 & 3 & 4 \\
\hline
\end{tabular}

* Fresh matter.

The mean bromide contents of the lettuce samples according to the country of origin are presented in Table 2.

Table 2. Distribution of bromide residues in lettuce according to countries of origin.

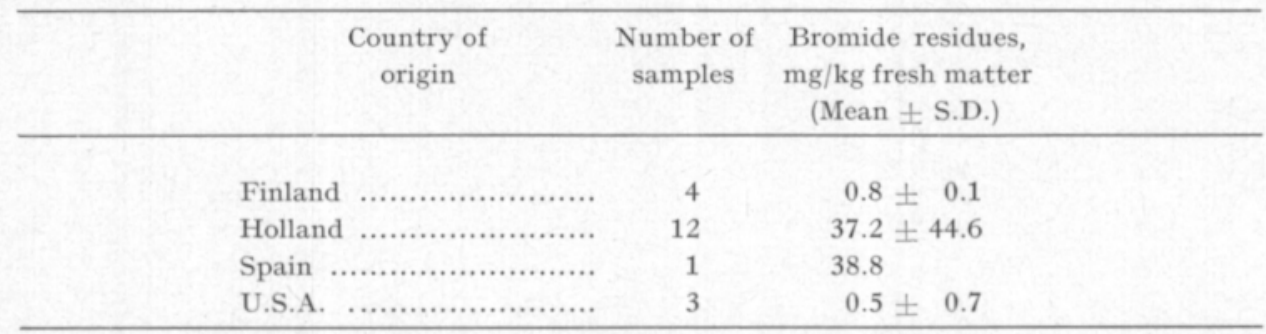




\section{Discussion}

Of the several methods used for the analysis of bromine in foods reviewed by Getzendaner 1975, the polarographic method seems to be the method of choice. It has good sensitivity and specifity and is quickly performed (Beckman et al. 1967). The modified polarographic technique used in the present experiments was found to be well suited for the purpose over a wide range of concentrations.

The results in Table 1 show that in 20 instances the bromide content was found to be in excess of $2 \mathrm{ppm}$ fresh matter, which is considered to be the natural bromide level of several vegetables (WAGNER et. al. 1971, STÄRK and Süss 1973). In 12 instances the level was exceeded in lettuce. Table 2 shows that the lettuce samples originating from Holland and Spain (1 sample) had the highest bromide contents. These are obviously due to the bromide treatment of the soil, since the mean bromide content of lettuce grown on untreated soil, according to STÄRK and Süss (1973), is $1.16 \mathrm{ppm}$, and bromide is known to accumulate in lettuce (Van WambeкE 1974).

Different countries and organisations have proposed different tolerance levels for bromide residue in vegetables (FAO/WHO 1973, Gollop 1974). E.g. in the Federal Republic of Germany the present maximum tolerable levels are $50 \mathrm{ppm}$ bromide in cucumbers, $30 \mathrm{ppm}$ in tomatoes and $5 \mathrm{ppm}$ in other vegetables in fresh matter (Johansson 1975). The same level of $5 \mathrm{ppm}$ has been accepted in the U.S.A. (Gollop 1974).

In the present work the 5 ppm level was exceeded by 10 samples, all of which were lettuce. The bromide content of the other vegetables studied were below the maximum tolerable levels noted here that especially crops where the green parts of the plant are consumed are known to concentrate bromine. The bromide contents of other vegetables, e.g. tomatoes, cucumbers and strawberries, are generally relatively low (Gollop 1974, JoHAnsson 1975).

Bromine is known to be a toxic substance to man and animals. The organism cannot separate bromide from chloride (Moeschlin 1972, Hapke 1975). Bromide is also known to catalyze the formation of carcinogenic N-nitroso compounds in an acid environment by the reaction of nitrite with certain nitrogen compounds (MrRvish 1975).

The maximum acceptable daily intake (A.D.I.) for bromine as established by the F.A.O. (Food and Agriculture Organization of the United Nations) and W.H.O. (World Health Organization of the United Nations) is $1 \mathrm{mg}$ per $\mathrm{kg}$ body weight (W.H.O. 1973). Althought the bromine content of a typical Finnish diet is not known, the bromide content found in the imported lettuces may significantly add to the present body burden of bromide for the Finns. 


\section{REFERENCES}

Beckman, H., Allen, P. T., Crosby, D. G., Gauer, W. O. \& Mourer, C. 1967. A polarographic method for bromide residue determination. J. Food. Sci. 32:595-598.

Getzendaner, M. E. 1975. A review of bromine determination in foods. J. of A.O.A.C. 58: $711-716$.

Gollop, Z. 1974. The problems of bromine residues after soil fumigation. Agric. Environm. 1: $317-320$.

HAPKE, H.-J. von. 1975. Toxikologie für Veterinärmediziner. 408 p. Stuttgart.

Hoffmann, G. M. \& Malkomes, H. P. 1974. Bromide residues in vegetable crops after soil fumigation with methyl bromide. Agric. Environm. 1: 321-328.

Johansson, C. E. 1975. Bromidhalter i saltade jordnötter, tomater och gurkor. (Summary). Vår föda $27,3: 1-4$.

Martin, H. 1972. Pesticide manual. 535 p. 3rd Ed. Nottingham.

Mrrvish, S. S. 1975. Formation of N-nitroso compounds: chemistry, kinetics, and in vivo occurence. Toxic. appl. Pharmac. 31: 325-351.

Moeschlin, S. 1972. Klinik und Therapie der Vergiftungen. 534 p. 5. Auflage. Stuttgart.

STÄRK, H. \& Süss, A. 1973. Bromgehalte von Gemüsepflanzen verschiedener Herkunft. (Summary). Nachrichtenbl. Deutsch. Pflanzenschutzd. 25: 87-91.

WAGNER, F., StÄRK, H. \& SÜss, A. 1971. Veränderung des Bromgehaltes in der Pflanze nach einer Bodenentseuchung mit Methylbromid. Gesunde Pflanze. 23: 221-223.

WAMвEKE, E. van. 1974. Bromide residues in lettuce after soil fumigation with methyl bromide, and some factors involved. Agric. Environm. 1:277-282.

W. H. O. 1973. Pesticide residues in foods. Wld Hlth Org. techn. Rep. Ser., No. 525.

Ms received April 28, 1976

\section{SELOSTUS}

\section{Eräiden suomalaisten ja tuontivihannesten bromipitoisuudet määritettynä polarograafisella menetelmällä}

Jorma Hirn'1), Ruth Stabel-Taucher ${ }^{2}$ ) ja Timo J. Pekkanen ${ }^{1}$ )

1) Eläinlääketieteellinen korkeakoulu, 00550 Helsinki 55

2) Valtion eläinlääketieteellinen laitos, 00550 Helsinki 55

Tutkimuksessa määritettiin 59 kotimaisen ja tuontivihannesnäytteen bromipitoisuudet käyttäen hyväksi sovellettua polarograafista menetelmää. Tutkimuksen yhteydessä todettiin kymmenen salaattinäytteen kahdestakymmenestä sisältävän enemmän kuin $5 \mathrm{mg} / \mathrm{kg}$ tuorepainoa bromia. Tämä arvo on asetettu alimmaksi raja-arvoksi esimerkiksi Saksan Liittotasavallassa. Raja-arvon ylittävät pitoisuudet tavattiin Hollannista ja Espanjasta tuoduista salaateissa. Bromin luonnollisen taustan, joksi on katsottu $2 \mathrm{mg} / \mathrm{kg}$ tuorepainoa, ylittäviä arvoja todettiin myös joissakin vihannessäilyke näytteissä sekä tomaatti- ja kurkkunäytteissä. 